\title{
THE IMBROGLIO ON TAX REFORMS TO FACILITATE ISLAMIC FINANCE IN NIGERIA: A CONTENDING BUT NOT CONTENTIOUS CONSTITUTIONAL ISSUE*
}

\author{
Olokooba Saka Muhammed ${ }^{1}$
}

\begin{abstract}
As Islamic Finance is developing in Nigeria, the urge to facilitate its taxability by the Nigerian government has also been gathering momentum. While some are in support of this idea, others contend that section 10 of the Constitution of the Federal Republic of Nigeria abhors state religion and by extension the tax reform to facilitate Islamic Finance, hence the imbroglio. This paper examines whether it is constitutionally possible for Nigeria to implement tax reforms to facilitate faith based financial transactions. This study considers the theoretical considerations
\end{abstract}

\footnotetext{
Apart from the three days workshop on the Taxation of Non-interest finance in Nigeria organised by the Federal Inland Revenue Services FIRS Abuja Nigeria, where the author presented a joint paper with Professor M.T. Abdulrazaq, the renown professor of Taxation in Nigeria which rekindled the author's interest in conducting further study into the constitutionality or otherwise of the tax reform to facilitate Islamic Finance in Nigeria, the author also acknowledges Brett Freudenberg and Mahmood Nathie for the great inspiration he derived from their paper titled "The Constitution and Islam: Are Tax Reforms possible to facilitate Islamic Finance?"

1 Senior Lecturer and Formerly, Coordinator, Department of Business Law, Faculty of Law, University of Ilorin, Ilorin, Nigeria, sakaskydlaw2002@gmail.com
} 
of taxes and religion and assesses the implications of Islamic finance in light of Nigerian constitutional provisions. The researchers conclude that even though the issue of tax reform to facilitate Islamic finance is contending, it isn't contentious. The reason for holding this position is that there are various sections in the Nigerian Constitution that allows for freedom of religion and Islamic cultures which include the Islamic financial system. However, for such reform to be viable, this paper recommends that it should be carried out in line with constitutional reforms and amendments without infringing upon the rights of other religious believers in Nigeria.

Keywords: Islamic finance, tax, religion, constitutionality, imbroglio

\section{INTRODUCTION}

One of the underlying reasons for the Federal Inland Revenue Services (FIRS)'s move to reform the Nigerian tax laws - so as to facilitate Islamic Finance - has been the surge in popularity for Islamic finance in Nigeria. Amongst the economic benefits of Islamic finance to Nigeria include the prospect of securing financial aid to finance the economy, maintaining Shariah compliant accounts, capital in stock markets, and Islamic bonds. Other advantages include acquiring the services of the financial specialist from OIC member states as well as Islamic Development Bank (IDB) to assist in standardising the nation's products. The significance of getting expert knowledge from OIC member states as well as IDB can never be over emphasised in regards to Nigeria achieving a profitable and workable Islamic financial system.

In fact, Nigeria has the potential to become the African hub for Islamic finance. As Abikan² states, Nigeria is home to the largest Muslim population in sub-Sahara Africa with around half of its 150 million people being members of the Islamic faith. The country is also home to one of Africa's fastest growing consumer and corporate banking sectors.

In 1992, Habeeb Nigerian Bank started interest-free banking and was the first bank to be issued a license to operate in $1997 .{ }^{3}$ Some conventional banks

2 Abikan I.A., 'Islamic Banking as Non-Interest Banking: Fact or Fiction?' The Jurist, (2011): 17.

3 V.C Oba 'Islamic Banking in Nigeria,' available at http://ssrn.com/ abstract $=2166538$, see also, S.M. Olokooba 'Taxation of Islamic Banking Products under the Nigerian Laws: Issues, Problems and Prospects', Bayero Journal of Islamic Law, 1/1 (2014): 5. 
in Nigeria are also trying their best to showcase and engage in advertising Islamic finance services. Amongst the pivotal Islamic finance products already available in most financial institutions in Nigeria - of which tax reforms is being intended - are murabahah (commercial funding with cost-plus), mudharabah (trust or passive partnership) and musharakah (active partnership). According to $\mathrm{CBN}$, "in the near future, products like sukuks (Islamic Bonds), ijarah (Leasing Contract) takaful (Mutual Insurance Arrangement) and wakalah (Profit-Sharing Agency) will be introduced and regulated in the Nigerian financial sectors." 4

Following this development and considering the brighter futures as well as viability of Islamic finance in the emerging global economy, since 2013 the Federal Inland Revenue Services of Nigeria has been exploring ways to find a common ground towards developing a legal framework for the taxation of Islamic Finance products in Nigeria. This was in line with the suggestion by Abdulrazaq, ${ }^{5}$ a professor of taxation and former registrar/chief executive of the Chartered Institute of Taxation of Nigeria stated - at the experimental stage of the non-interest finance system in Nigeria - that:

"There is an urgent need for the National Assembly to issue statutory instruments to regulate Islamic finance arrangements or more radically, for the Minister of Finance on the advice of the Federal Inland Revenue Service to propose regulations for the taxation of Islamic products..."

Even though the idea of venturing into faith-based finance may seem economically viable, one should consider the antagonistic efforts against Shariah implementation in Nigeria in the past as well as similar condemnations during the introduction of non-interest banking services in Nigeria in 2010. These condemnations were led by the fundamental question: what is the appropriateness and constitutionality of reforming the Nigerian tax laws to facilitate Islamic finance?

There is no doubt that this question was to continue underpinning efforts against the establishment of Islamic finance until the then Central Bank

4 A.U. Bashir, 'Regulatory and Legal Framework for Non-Interest Finance in Nigeria', A paper presented at a workshop on Taxability of Non-Interest Finance in Nigeria, organized by the Federal Inland Revenue Services, Abuja, 9-10 October, 2013

5 See Abdulrazaq M.T 'Are Islamic Financial Products Taxable in Nigeria?', (Unpublished paper, Author's private collection), 1-20 at 2. See also Abdulrazaq M.T. 'Banking and Taxation in the Name of God', Business Day (Nigeria), 7th July, 2011 at 4 
governor of Nigeria, now the Emir of Kano, His Royal Highness Sanusi Lamido Sanusi, declared in $2013^{6}$ that the introduction of Islamic banking in Nigeria is constitutional because sections 9, 23, and 52 of the Bank and Other Financial Institutions $\mathrm{Act}^{7}$ provides for its establishment in Nigeria.

\section{CONCEPTUAL FRAMEWORK}

Following the recognition and approval of Islamic banking in Nigeria by the Central Bank of Nigeria in 2010, coupled with the enthusiasm of most Nigerian banks (even the conventional ones) to finally be able to venture into Islamic finance. The Federal Inland Revenue Service in 2013 organised a three day workshop in the Federal Capital Territory, Abuja with the aim of developing a workable and practicable legal framework for the taxation of Islamic banking and finance products using the Nigerian tax legislations in such a way that it will not infringe on the strict rule of Islamic law. In that workshop, academics, tax practitioners, as well those working in the banking sectors brainstormed on how to achieve the set objectives. While Dr Hassan ${ }^{8}$ and Dr. Bashir ${ }^{9}$ used their experience in JAIZ bank as well as Central Bank of Nigeria to highlight the problems facing non-interest banking in Nigeria, Abdulrazaq ${ }^{10}$ and Olokooba ${ }^{11}$ spoke from a more academic perspective. ${ }^{12}$ In a similar effort, the Niger Insurance Company Plc in 2014 also organised a follow up workshop in Lagos on the tax aspect of Islamic Insurance (takaful). In those workshops, though it was agreed that the current Nigerian tax legislations must be reformed

\footnotetext{
$6 \quad$ See Vanguard Newspaper of 06 August, 2013 at 13.

7 Cap. B3 Laws of the Federation of Nigeria 2004.

8 Hassan U is one of director JAIZ bank, Abuja Nigeria

9 Bashir A.U is also a director in the Central Bank of Nigeria, Abuja

10 Abdulrazaq is a Professor of Taxation, one time Registrar/Chief Executive, the Chartered Institute of Taxation of Nigeria and Current Dean of Law, Lagos State University, Nigeria.

11 Olokooba is Senior lecturer in Revenue Law, Faculty of Law, University of Ilorin, Nigeria

12 See U. Hassan, 'An Overview of Non-Interest Finance', A paper presented at workshop on Taxability of Non-Interest Finance in Nigeria, organized by the Federal Inland Revenue Services, Abuja, 9-10 October, 2013, A.U. Bashir, 'Regulatory and Legal Framework for Non-Interest Finance in Nigeria', A paper presented at a workshop on Taxability of Non-Interest Finance in Nigeria, organized by the Federal Inland Revenue Services, Abuja, 9-10 October, 2013; M.T. Abdulrazaq and S.M. Olokooba, 'Tax Issues in Non-Interest Finance Transaction', A paper presented at a workshop on Taxability of Non-Interest Finance in Nigeria, organized by the Federal Inland Revenue Services, Abuja, 9-10 October, 2013.
} 
to facilitate Islamic finance, the mode and nature such reforms was never addressed.

\section{THEORETICAL ISSUES}

\section{Notional Consideration of The Principles of Islamic Finance}

Islamic finance is a mode of financial intermediation consistent with the principles of Islamic law. ${ }^{13}$ The notion of Islamic finance encompasses both banking and other Islamic financial dealings. The cardinal principles of Islamic finance rests on compliance with the Divine injunction of Allah as stated in the Shariah. ${ }^{14}$ Some of the criteria for something to be considered within the bounds of Islamic finance, according to Brett and Mahamood, ${ }^{15}$ are the recognition of money and capital as a means of exchange and not as tradable commodities, clear prescriptions on what is permissive as well as prohibited, and identifying as well as defining the similarity and dissimilarity between profits and risks. The essence of all these aspects is to achieve the apex of social responsibility expected of all parties in Islamic financial transactions. While the principles and limitations are generally set by the Shariah, the legal interpretations as well as applications are to be found in Islamic jurisprudence (i.e. fiqh).

Islamic finance, when meticulously practiced and followed, is premised on good ethical values between parties to achieve fair and equitable treatment in the course of any and all financial transactions. Consequently, transactions, obligations, and contracts in line with Islamic finance must do away with interest (i.e. riba) and must not include prohibited acts and investments. Allah states in the Holy Qur'ān:

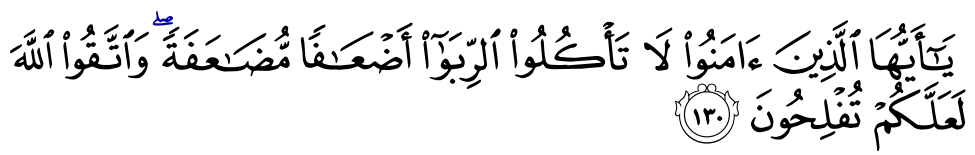

"O you who believe, eat not riba (usury) double and multiplied, but fear Allah that you may be successful..."

(Surah Āli 'Imrān, 3: 130)

13 B.D. Ahmad, 'Principles of Islamic Banking' in Readings in Islamic Banking and Finance, ed. U.R. Shehu Aliyu et al. (Kano: International Institute of Islamic Banking and Finance, Bayero University, 2013), 60.

14 N. Yaqubu, 'Shariah Requirements for Conventional Banks,' Journal of Islamic Banking and Finance, 22 (2005): 1.

15 Brett F. \& Mahmood N., 'The Constitution and Islam: Are Tax Reforms Possible to Facilitate Islamic Finance?', Revenue Law Journal, 20/1 (2010): 2. 
The major dichotomy between Islamic finance and the conventional finance system is that the former operates in accordance with the principles of Shariah while the latter operates by manmade law. Another characteristic of Islamic finance that differentiates it from conventional finance is that while the latter primarily emphasises and utilises paper money, Islamic finance flourishes more on assets. Similarly, while interest on capital or investment and speculation are allowed in conventional trading, all of these are forbidden in Islam, which promotes equitable treatment between parties and equal sharing of both profit and loss.

\section{The Cardinal Principles and Constituents of Islamic Finance}

Basically, the underpinning norms that characterise Islamic finance are two: moral-ethics and economic norms. The former is based on socio-economic justice and equitable distribution of wealth through tax, whereas the latter abhors engagement in prohibited trade and businesses.

The economic aspect of the cardinal principles of Islamic finance varies and is broad in nature. In fact, the juristic principles underpinning these elements are vast and go into very fine details for which there is no consensus among the four leading Islamic juristic schools. ${ }^{16}$ However, this does not mean that there are no distinct features or characteristics by which to identify the constituent of Islamic finance.

A contextual analysis of Islamic financial practices point to the fact that it is strictly based on the Shariah provisions that prohibit usury, which absolutely prohibit the receipt or payment of any predetermined guaranteed rate of return, thereby closing the gate to the concepts of interest in financial dealings. ${ }^{17}$ Islamic banking and finance also rules out the use of debt-based instruments and reprehends speculative behavior in business. ${ }^{18}$ It promotes risk-sharing, equitable participation of parties, sanctity of contracts, and encouragement of entrepreneurship.

16 Brett F. \& Mahmood N., 'The Constitution and Islam: Are Tax Reforms Possible to Facilitate Islamic Finance?' 9.

17 See Āli 'Imrān (3: 130). See also A.B Dogarawa \& M.S. Bello, 'Achieving Financial Inclusion in Nigeria: What Role for Non-Interest Banking?' Bayero International Journal of Islamic Finance, (2014): 92-93.

18 Z. Iqbal, 'Islamic Financial Systems', Journal of Finance and Development, 34/2 (1997). 
The Imbroglio On Tax Reforms to Facilitate Islamic Finance in Nigeria: A Contending But Not Contentious Constitutional Issue

Ahmad ${ }^{19}$ posited that Islamic finance rests on seven principles: the prohibition of riba (interests), prohibition of maysir (gambling), avoidance of gharar (uncertainty), subject of sale must be Shariah compliant, and be activity must be for socio-economic benefit. Brett and Mahamood ${ }^{20}$ while citing Obaidullah ${ }^{21}$ also listed seven distinct cardinal principles of Islamic finance:

1) Freedom to contract (Surah al-Baqarah, 2: 275; Surah al-Nisā', 4: 29)

2) Freedom from riba as (Surah al-Rūm, 30: 39; Surah al-Nisā', 4: 161; Surah Āli 'Imrān, 3: 130-2; Surah al-Baqarah, 2: 275)

3) Avoidance of gharar or excessive speculation and uncertainty

4) Freedom from al-qimar (gambling) and al-maysir (un earned income)

5) Avoidance of trading and investing in forbidden acts and objects (such as pornography and alcohol)

6) Risk sharing

7) Asset-based financial transaction based on the condition that identifiable and tangible underlying assets should underpin financial transactions.

To regulate the practice of Islamic finance in Nigeria some guidelines for practice and procedure were developed to serve as guidelines. Thus, apart from the guidelines compiled by the Islamic Finance Services Board, the Accounting and Auditing Organisation for Islamic Financial Institutions (AAOIFI), and the Nigerian Accounting Standard Board (NASB), the Central Bank of Nigeria, under section 33(1) (b) Central Bank of Nigeria Act $^{22}$ as well as section 23(1); 52, 55(2) 59(1)(a) and 61 Banks and Other Financial Institutions Act, ${ }^{23}$ along with section 4(1) of the scope of Banking Activities and Ancillary Matters No 3, 2010 serve as regulatory statutes for Islamic finance in Nigeria.

\footnotetext{
19 B.D. Ahmad, 'Principles of Islamic Banking,' 61.

20 Brett F. \& Mahmood N., 'The Constitution and Islam: Are Tax Reforms Possible to Facilitate Islamic Finance?' 9.

21 M. Obaidullah, Islamic Finance Services (Jeddah: King Abdul-Aziz University, 2006), 10-12.

22 Cap C 4 Laws of the Federation of Nigeria (2004).

23 Cap B 3 Laws of the Federation of Nigeria (2004).
} 


\section{Juxtaposition of the Islamic and Conventional Tax Policy}

Taxation policy, as understood from the works of early Islamic scholars and adapted by the early Islamic polity, seems to be guided by the basic ethos of Shariah and is intended for the welfare of the people. ${ }^{24}$ Such a policy meets the criteria of equity, justice, and wealth redistribution. Taxation in Islam was meant for the achievement of certain specific social and economic ends within the general framework of Islam..$^{25}$

Revenue from taxes is to be used for the general welfare of the populace. The essence of the use of revenue derived from tax for the welfare of the people could be gleaned from the distinct ways Allah commanded zakāh to be distributed. ${ }^{26}$ Zakāh is compulsory alms imposed on Muslims that possess the nisab that is, an approved measurement of value of a particular things or items that can be use for zakāh which must be given to the eight asnaf-eligible beneficiary of zakāh identified in the al-Qur'ān. ${ }^{27}$ Tax in Islam purifies the wealth of the rich while it also ameliorates the suffering of the poor.

During the early history of the Islamic polity, zakāh was the only Islamic fiscal duty (in form of tax) collected from Muslims whose wealth satisfied the requirement for its collection. In fact, until the time of the second Caliph 'Umar Ibn al-Khatțab RA when other forms of taxes like kharāj, the land tax, ' $u s h r,{ }^{28}$ farm produce tax, 'ushr, a charged on traders who entered the Islamic polity to conduct trade and jizyah ${ }^{29}$ which was the lump-sum tax applied to all mature, male (non-Muslim) who enjoy security and protection from Islamic

24 Sabahuddin Azmi, Islamic Economics (New Delhi, India: Goodword Books, 2004), 95.

25 A.B Dogarawa and M.S. Bello, 'Achieving Financial Inclusion in Nigeria: What Role for Non-Interest Banking?' 96.

26 The issue of zakāh and its distribution are stated in many verses of Qur'ān, but it is more detailed in Surah al-Tawbah (9: 60) and Surah al-Hajj (22: 78). Summarily, zakāh are for the poor, miskin, collectors, on the cause of Allah, indebted, freeing slaves, mu'allaf, travelers that fall short of funds.

27 AD Muhammed, N Oladokun \& M.D.F Amin, 'Zakah Distribution among Asnaf in Wilayah and Selangor: An Analytical Hierarchy Process,' Bayero International Journal of Islamic Finance (2014): 39.

28 'Ushr is usually a tenth of gross agricultural output which is not by irrigation and one fifth if by irrigation. The 'ushr tithe is only due if the produce is available, but if there are any natural disasters to the produce, then that made the payment of tithe lapse.

29 Jizyah is levy only on those with means to pay. The rich pays 48 dirham, the middle class, 24 dirham and the lower class 12 dirham. Surah al-Tawbah (9:29) enjoins the collection of this type of tax. 
state came into being, the only major source of revenue to manage the state affairs was zakāh. ${ }^{30}$

While some Muslim jurists supported the introduction of other forms of taxes apart from zakāh by the Islamic polity, some Islamic scholars opined that even though sadaqah, a charity done on compassion and any other free will gifts are permitted in Islam, no other forms of taxation are allowed in Islam. Those that supported any other types of tax based their argument on mașlahah (i.e. the common good of the society). ${ }^{31}$ However, those who opposed the levying of other forms of taxes argued in line with the Islamic principles of protection of and sanctity of private property. To this class of jurist, any imposition of other forms of tax apart from zakāh is consider the unlawful consumption of other's wealth and it is against the Qur'anic provision:

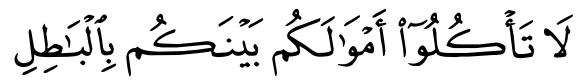

"And do not consume one another's wealth unjustly." 32

(Surah al-Baqarah, 2: 8)

Unlike the conventional tax system, the Islamic notion of taxation has to do more with wealth redistribution and less on income generation or income accumulation. The equity and welfare of the citizenry are the basic concepts of Islamic taxation. Taxation under Islamic finance lays greater emphasis on wealth rather than income. Under the Islamic principle of finance, an average income earner enjoys greater leverage with more disposable income which then promotes greater spending in the economy and boosts real sector activity. ${ }^{33}$ Therefore, one of the fundamental aspects of the Islamic taxation policy is that only the rich and prosperous that has sufficient resources to pay and are able to bear the main burden of taxes are subject to taxation. ${ }^{34}$

Another feature that dichotomises the Islamic taxes from conventional taxes is in the mode and manner of its assessment, collection, and payment.

30 M.A. Ishaq, S.U.R. Aliyu \& B.T. Jibril, 'Principle of Islamic Taxation,' in Readings in Islamic Economy, ed. URA. Shehu et al. (Kano: International Institute of Islamic Banking and Finance, BUK, 2013), 96.

31 M.A. Ishaq, S.U.R. Aliyu \& B.T. Jibril, 'Principle of Islamic Taxation,' 98.

32 For other arguments and reasons why some jurists opposed to other forms of tax save zakāh, see M.A. Ishaq, S.U.R. Aliyu \& B.T. Jibril, 'Principle of Islamic Taxation,' 98-99.

33 Brett F. \& Mahmood N., 'The Constitution and Islam: Are Tax Reforms Possible to Facilitate Islamic Finance?' 96.

34 Sabahuddin Azmi, Islamic Economics, 106. 
While the equitable redistribution of wealth achieved through convenience and willingness of the taxpayers to pay constitutes the major feature of the Islamic tax system. ${ }^{35}$ Rich or poor, able or not able, failure of any male adult to pay tax under conventional tax law is criminal in nature and will be treated as tax evasion. ${ }^{36}$

Taxes in Islam are viewed as a trust in the hands of the state which must be handled carefully and used judiciously. Thus, in the Islamic tax system, people have the right to question the use of their tax revenue, whereas under the conventional tax system, the issue of taxes is non-negotiable. Other notable principles of Islamic taxation, as outlined in M.A. Ishaq et al, ${ }^{37}$ are that taxes in Islam should be levied, taking into consideration and based on mutual consent and satisfaction, least burden, careful handling, equity, simplicity, efficiency, economy, flexibility, and productivity. ${ }^{38}$

The associated complexity and technicality in the linguistic content of most conventional tax systems, especially with regard to interpretation as well as understanding of legal language, is not present in the Islamic tax system. While conventional taxes rests on human reasoning and manipulative tendencies, Islamic taxes are based on the Divine words of Allah and the Sunnah - the sayings, actions and tacit approval of the holy Prophet Muhammad SAW

35 Surah al-Tawbah (9: 103) enjoins the state to collect zakāh, but the hadīth of the holy prophet (SAW) explains how it should be collected. In one of the hadith narrated by Bukhārī \& Muslim, the Prophet was reported to have appealed to collectors of zakāh to be merciful. According to another hadìth, Ibn 'Abbās reported that when the prophet Muhammad (SAW) sent Mu'adh Ibn Jabal to Yemen to collect zakāh, he was warned by the prophet thus, "do not take as a zakāh the most desired of their wealth". See also, M.A. Ishaq, S.U.R. Aliyu \& B.T. Jibril, 'Principle of Islamic Taxation,' 101.

36 In Michigan Employment Sec Commission v. patt 4 Mich-App 24414 N.W $2^{\text {nd }}$ 663 , tax is said to be "a non voluntary or donation, but an enforced/compulsory contribution exacted pursuant to legislative authority." In Shell v. FBIR (2004) FNLR 859,46 , tax is said to be "a debt that must be compulsorily paid to government."

37 M.A. Ishaq, S.U.R. Aliyu \& B.T. Jibril, 'Principle of Islamic Taxation,' 101-103.

38 M.A. Ishaq, S.U.R. Aliyu \& B.T. Jibril, 'Principle of Islamic Taxation,' 101-103. 
The Imbroglio On Tax Reforms to Facilitate Islamic Finance in Nigeria: A Contending But Not Contentious Constitutional Issue

which must not be manipulated to the advantage of others, but rather must be obeyed to the letter. ${ }^{39}$

The state's right to raise resources through taxes in Islam, according to Chapra, is legitimised because such an action is in consonance with the Prophetic practice. However, while assessing these levies, it must not be done in an unjust manner that will bring hardship on the taxpayers. As Chapra states: ${ }^{40}$

“... in your wealth there are also obligations beyond the zakāh, and of the fundamental principles of Islamic jurisprudence is that a small benefit may be sacrificed to attain a larger benefit and a smaller sacrifice may be impose in order to avoid a larger sacrifice...."

However, such right is not unfettered because,

“...while Islam does allow the levying of taxes to a reasonable extent to meet all necessary and desirable state expenditures, it does not permit an unjust tax structure which penalises honesty and creates an un-Islamic tendency of evading taxes..." 41

Given the aforementioned, it could be gleaned that levying of other forms of taxes apart from zakāh by the state is permissible. However, the state should desist from imposing a levy that will inflict hardship on the taxpayers.

\section{ANALYSING THE CONTENDING ISSUES IN THE CONSTITUTIONALITY OF TAX REFORM TO FACILITATE ISLAMIC FINANCE IN NIGERIA}

\section{Tax as a Constitutional Obligation}

Payment of taxes is a constitutional obligation. For this, Section 24(f) of the 1999 Constitution of the Federal Republic of Nigeria enjoins all citizens of Nigeria to declare his/her income honestly and pay his/her taxes promptly.

39 For some of the negative effects of the ambiguity in tax language, see S.M. Olokooba, A.A. Kareem \& L.K Zakarriyah, 'Ambiguities in the Nigerian Tax Laws', Ife Juris Review, 3 (2014): 725-730. See also, M.K Adebayo \& S.M. Olokooba, 'The Memorandum of Understanding on Double Taxation between Nigeria and Kenya: An Appraisal', Africa Nazarene University Law Journal, 3/1 (2015): 115-116.

40 M.U. Chapra, Towards a Just Monetary System (Leicester UK: The Islamic Foundation, 1985), 160.

41 M.U. Chapra, Towards a Just Monetary System, 89. 
According to the section, "It shall be the duty of every citizen to declare his income honestly to appropriate and lawful agencies and pay his tax promptly."

Any individual or corporate organisation that refuses to pay taxes is said to have evaded taxes thereby committing a punishable offence. ${ }^{42}$ As an African, the African Charter provides that every individual has a duty to work to the best of his or her ability and competence and to pay taxes imposed by law in the interest of the society. ${ }^{43}$ While the protocol to African Charter on Human and People's Right provides that states shall ensure the equal application of taxation laws to women and men to avoid tax discrimination against women. ${ }^{44}$

\section{Tax Treatment of Religious Institutions in Nigeria}

In Nigeria, religious organisations are regarded as ecclesiastical bodies. This is so because they are not registered to make profit or engage in trade or business. Section 23(c) of the Companies Income Tax Act ${ }^{45}$ and section 19(1) paragraph 3 of the $3^{\text {rd }}$ Schedule of Personal Income Tax Act ${ }^{46}$ exempts from tax the profit of any company engaged in ecclesiastical charity or educational activities of a public character insofar as such profits are not derived from a trade or business carried on by such company. For this, the Nigerian tax law could be said to have adequately protected churches, mosques, and other charitable organisations against the payment of tax.

The peculiarity and preferential tax treatment of religious institutions in Nigeria has constitutional support, however it is abused by some religious leaders who live lavish lifestyles while most of their at congregations are languishing in abject poverty. ${ }^{47}$ For this, arguments have been advanced against

42 See Part IV Taxes and Offences in Section 40-49, Federal Inland Revenue Services Act, No. 13 (2007).

43 Article 28 (b) African Charter on Human and People's Right.

44 Article 13 (b) Protocol to the African Charter on Human and People's Rights, on the right of Women in Africa adopted in Maputo in 2003. See also Oladoyin \& Olufemi, 'Taxation of Religious Bodies in Nigeria', Modern Trend in Tax Law, Administration and Practice in Nigeria: Essay in Honour of Chief Olusola Adekanola, ed. O. Abifarin (Makurdi: Juniper Publications, 2013), 177.

45 Cap. C 21 Laws of the Federation of Nigeria, 2004

46 Cap. P 8 Laws of the Federation of Nigeria, 2004.

47 In Nigeria, pastors like Ayo Oritseja for (President of the Christians Association of Nigeria), Bishop David Oyedepo (General overseers Living Faith (Winners) Church), Enoch Adeboye of Redeemed Christian Church of God (RCCG) and T.B. Joshua of Synagogue Church of All Nations (SCOAN), Joseph Agboli Victor 
the tax immunity of religious bodies due to observed inequalities. ${ }^{48}$ Nigerians therefore have started asking religious leaders using private jets to account for their personal finances. ${ }^{49}$

In the opinion of those opposing tax exemptions for religious bodies, the burden of taxation is now heavier on the Nigerian economy because of said exemptions. ${ }^{50}$ The gist of their argument is that the failure of religious institutions to pay taxes directly affects the revenue base of the country and results is the availability of extra funds for religious leaders to spend extravagantly. Hence, the flamboyant life style of most religious leaders in Nigeria.

Despite this negative effect, the position of the law with regards to tax treatment of religious organisation in Nigeria still remains that once any such organisation is registered under part $\mathrm{C}$ and not part $\mathrm{A}$ of the Companies and Allied Matters Act, ${ }^{51}$ any donation made to them in cash or in kind, in order to assist them to carry out their objectives, are tax deductible. ${ }^{52}$ However, on the contrary, section $31(\mathrm{a})(\mathrm{a})^{53}$ states that religious institutions which have made gains or profit, any trade, business, profession, or vacation from other sources inside or outside Nigeria, then such income is susceptible to tax. ${ }^{54}$ The implication of this provision is that as far as the current position of the law in Nigeria is concerned, there is no way a church, mosque, or other

(Victories Army Ministries) own private jets and expensive cars. For details and comprehensive list of all religious leaders living extravagant lives in Nigeria, see, 'Pastors and Preachers who own private jet in Nigeria,' available at nairabrains. com/2014/10/pastors-and-prechers-who-own-private-jets-in-Nigeria/. See also, Joseph Edgar, 'Pastors Private Jets and their Taxes', Daily Post $18^{\text {th }}$ September, 2015. Further see, Kemi Lawal \& Allwell Okpi, 'Okotie buys N120M Rolls Royce to Mark Pastoral Anniversary,' Sunday Punch 22 ${ }^{\text {nd }}$ December 2013.

48 See Kemi Lawal \& Allwell Okpi, 'Okotie buys N120M Rolls Royce to Mark Pastoral Anniversary.'

49 See, 'The Private Jet, the Church and Nigerians,' Vanguard, 03 October 2013, 4.

50 Murphy J. made similar observation in the case of Australia in Church of the New Faith v. Commissioner of Payroll TR 794. Also see, Brett F. \& Mahmood N., 'The Constitution and Islam: Are Tax Reforms Possible to Facilitate Islamic Finance?' 17.

51 Cap. C20 Laws of the Federation of Nigeria, 2004. Part A of Companies and Allied Matters Act is on Company Incorporation. Any company incorporated under part A are not tax exempt.

52 See section 21 (4) (5) and section 21(a) (1) \& (3), Companies Income Tax Act (2004).

53 Personal Income Tax Act (2004).

54 See section 3 (1) (a), Personal Income Tax Act (2004). 
charitable organisation will pay tax except if the law is amended. However, pending such amendment, the best alternative being proposed now is that a charities commission be set up by government to register, regulate, and control all charity organisations and their activities in Nigeria. ${ }^{55}$ The reason why this is being advocated for is that strict control of such organisations sill help government to monitor both the inflow and outflow of funds.

\section{Contending Issues in the Constitutionality of Tax Reform to Facilitate Islamic Finance in Nigeria}

In determining the constitutionality of tax reforms to facilitate Islamic finance in Nigeria, it is critical to appraise the relationship between the religious freedoms enshrined in section 38(1), the prohibition of state religion in section 10 , as well as the federal legislative power to tax in section 4(2) - all within the Constitution of the Federal Republic of Nigeria. According to Section 4(2):

$$
\begin{aligned}
& \text { "...The National Assembly shall have power to make laws for } \\
& \text { peace order and good government of the federation or any part } \\
& \text { therefore with respect to any matter included in the Exclusive } \\
& \text { Legislative List set out in part } 1 \text { of second schedule to this } \\
& \text { constitution..." }{ }_{56}
\end{aligned}
$$

The power to tax is vested in both the federal as well as the state legislatures. Each of these powers is stated in both the exclusive legislative list and the concurrent legislative list. The powers to tax in the former belong to the federal legislatures, while both the federal and state legislatures can legislate on items in the latter.

On the other hand, Islamic finances are transactions and contracts in line with the principles of Islam and devoid of usury. The power to tax this financial system has yet to be enshrined in the Nigerian Constitution. For this, such power as of now is outside the constitutional jurisdiction of Nigeria legislatures. Be that as it may, it will be pertinent to examine if it will be appropriate to reform a law regarded as "secular" by some people for the benefit of a faith-based financial system considering the prohibition of establishing a state religion in

55 See 'The Private Jet, the Church and Nigerians,' Vanguard, 03 October 2013.

56 Items 59 on the said second schedule contain 'Taxation of Incomes, Profits and Capital Gains...' Similarly, the state legislatures in items 7 (a) Concurrent Legislative List are empowered to legislate on tax or duty on Capital Gains, incomes from profits of persons other than companies...." 
section 10 of the Nigerian Constitution. ${ }^{57}$ Will a reform to facilitate faith-based finance be tantamount to an indirect imposition of belief on Nigerians?

The taxing power of the National Assembly is very broad and incontestable..$^{58}$ In fact, the unlimited nature of the legislator's power to tax seems to be far and above the statutory purpose or motive of tax legislations with relevance to the economic consequences of tax..$^{59}$ Taxation power is not limited to the raising of revenue alone; for government purposes, a wide range of objectives, such as fiscal, social, and economic policies may be achieved through "tax" legislation. ${ }^{60}$ In Melbourne v. Commonwealth, ${ }^{61}$ Kitto $\mathrm{J}$ invoked the seminal proposition of Dixton $\mathrm{J}$ that:

"...If a law, on its face is one with respect to taxation, the law does not cease to have that character simply because parliament seeks to achieve by its enactment, a purpose not within Commonwealth legislative power (in this case tax reform to facilitate faith-based finances).. " 62

While legislating on tax reform to facilitate Islamic finance in Nigeria, the primary power that the federal legislature could rely on would be section 4(2) of the constitution which among the 59 items on the exclusive legislative list provide that the legislatures are empowered to make law with respect to "taxation of incomes, profits and capital gains, except as otherwise prescribed by this Constitution especially with regards to companies." ${ }^{63}$ The capital gains, income or profits of persons other than companies are what the state can legislate upon. ${ }^{64}$

However, the extent to which the provision in section 10 may invalidate the legislative power to tax pursuant to sector 4(2) has not yet been tried in any of

\footnotetext{
57 See section 10, Constitution of Federal Republic of Nigeria (2011).

58 Isaac J. (dissenting) in $R v$. Barger (1908) 6 CLR 41, 94-5.

59 Mac Cormick v. Federal Commissioner of Taxation (1984) 158 CLR 22.

60 R.E. Krever \& G. Kewley, Australian Taxation: Principles and Practice (Cheshire: Longman Cheshire, 1987), 39; Osborne v. Commonwealth (1911) 12 CLR 321; Brett F. \& Mahmood N., 'The Constitution and Islam: Are Tax Reforms Possible to Facilitate Islamic Finance?', 28. See also Fairfax FCT (1965) 114 CLR 1.

${ }^{61}$ Melbourne v. Commonwealth (1947) 74 CLR 31; Brett F. \& Mahmood N., 'The Constitution and Islam: Are Tax Reforms Possible to Facilitate Islamic Finance?', 29.

62 Emphasis mine

63 See, item 59, Exclusive Legislative List.

64 See item 7 (a), Concurrent Legislative List.
} 
the Nigerian courts of law, but a similar issue occurred in an Australian case of Halliday v. The Commonwealth of Australia. ${ }^{65}$ In that case, the applicants sought declarations to set aside the validity of a New Tax System (Goods and Services Tax) Act 1999 (Cth) (GST) in so far as it related to the imposition of tax collection by persons to forward it to the Commonwealth. One of the tax payer's assertions in that case was that the acts used to establish the GST contravened S.116 of the Australian constitution, in that they force certain citizens demands contrary to their religion.

Sundberg J. dismissed the validity of this plea and further held that even though the collection of GST may look offensive to some religious beliefs, since it does not prohibit the doing of any act in the practice of any other religion, it is constitutional.

The limitation that a religious belief can pose to tax is curtailed once said proposed tax does not infringe on the practices of freedom of religion and is beneficial to society as a whole. Lending credence to this position, Sundberg $\mathrm{J}{ }^{66}$ further held that:

"The court has long recognised that balance must be struck between the value of the comprehensive social security system, which rests on a complex of actuarial factors, and the consequences of allowing religiously based exemptions.... Religious beliefs can be accommodated..., but there is a point at which accommodation would radically restrict the operating latitude of the legislature. Because the broad public interest in maintaining a sound tax system is of such a high order, religious belief in conflict with the payment of taxes affords no basis for resisting the tax..."

The extent to which section 10 will invalidate the legislative power to reform taxes to facilitate a faith-based finance is further curtailed by the sociopolitical practices of all tiers of government in Nigeria which use the citizen's tax money to sponsor Muslim pilgrimage to Mecca and Christian pilgrimage to Jerusalem. The absence of any official gazette or law against this practice shows that it is not unconstitutional but rather for public interest and benefit.

${ }^{65}$ Halliday v. The Commonwealth of Australia (2000) FCA 950; as cited in Brett F. \& Mahmood N., 'The Constitution and Islam: Are Tax Reforms Possible to Facilitate Islamic Finance?', 31.

66 Brett F. \& Mahmood N., 'The Constitution and Islam: Are Tax Reforms Possible to Facilitate Islamic Finance?', 33. 
Juxtaposing this action with the argument of the tax reform antagonists that Nigeria is a secular state, one is bound to wonder about the veracity of such an argument. The reason being that, in a secular state, there is no place for religion in the affairs of the state, ${ }^{67}$ but in the case of Nigeria, government are deeply involved in the religious issues to the extent of sponsoring people for sacred pilgrimages. If all these could then be accommodated without any negative reaction, then the issue of mere tax reform to facilitate Islamic finance cannot amount to a breach of the constitution.

Not surprisingly, some Christian leaders and judges in Nigeria, like Justice Niki Tobi and ArchBishop John Onaiyekan, contended that a rightful application of literal, golden, and mischief rules of interpretation of section 10 of the Nigerian constitution shows that Nigeria is not a secular state. While using literal rule of interpretation, the words used in a statute are to be construed in their usual and ordinary grammatical sense especially when the wording is clear and unambiguous. ${ }^{68}$ However, if it is golden rule of interpretation, the interpreter should go beyond the ordinary meaning of words used in the statute to ascertain the legislative intent. This rule was laid down in the case of Beck v. Smith. ${ }^{69}$ The mischief rule of interpretation as laid down in Heydon's case ${ }^{70}$ is aimed at achieving the general policy of the statute by suppressing the evil the statute intends to avoid. ${ }^{71}$ In the words of Retired Justice Niki Tobi (JSC):

“... There is the general notion that section 11 of the 1989 (which is the equivalent of s.10 1999 constitution) makes Nigeria a secular nation. That is not correct. The word secular etymologically means pertaining to things not spiritual, ecclesiastical or not concerned with religion. Secularism, the noun variant of the adjective, secular, means the belief that the state, morals, education etc should be independent of religion. What section 11 is out to achieve is that Nigeria cannot for example adopt either

\footnotetext{
67 A.S. Hornby, Oxford Advanced Learners' Dictionary of Current English (London: Oxford University Press, 2004), 1062.

68 See, $R$ v. Bangaza (1960) 5 F.S.C. 1.

69 Beck v. Smith (1836) 2 M\&W 191, 195. See also, Akinosho v. Enigbokan (1955) 2 N.L.R 88.

$70 \quad$ Heydon's case (1584) 3 Co: Rep 7.

71 For other rules of interpretation as well as their applicability in the interpretation of the tax statutes, see S.M. Olokooba, A.A. Kareem \& L.K Zakarriyah, 'Ambiguities in the Nigerian Tax Laws', 725.
} 
Christianity or Islam as state religion. But that is quite different from secularism..." 72

Similarly, the then Catholic Archbishop of Abuja, John Onaiyekan, ${ }^{73}$ aptly captured the practical effect of section 10 on the secular status of Nigeria when he said:

“...what exactly does paragraph 10 of our constitution mean? We know for sure that the government is in many ways involved with religion. Our leaders often call on the name of God and religious services are held in many state occasions. We also have chaplaincies not only within the Armed forces but also in our government institutions of higher learning... Similarly, government has been financing national ecumenical centre. All these are issues where government has become justifiably; in my opinion involved in religion..." 74

Others, including academics, have also argued in favour of this position. ${ }^{75}$

72 Niki Tobi (JCA) 'Law, Religion and Justice' in Fundamental Legal Issues in Nigeria: Essays in Honour of Andrew Obaseki JSC, ed. O. Wole (Rtd) (Lagos: Patlink Publishers, 1995), 139.

73 John Onaiyekan, 'The Shariah in Nigeria; Issues and Perspectives,' (A Paper delivered at the National Seminar on Shariah Organised by Jamaatu Nasril Islam, 2000), 8-9.

74 John Onaiyekan, 'The Shariah in Nigeria; Issues and Perspectives,' 9.

75 See H.A. Yadudu, 'The Shariah Debate in Nigeria: Time for Reflections,' (A Paper delivered at the National Seminar on the Place of Women under the Shariah, Organised by Constitutional Rights Project, 2000); I.A. Abikan, 'Constitutional Impediments to the Total Enthronement of Shariah in Nigeria,' in A Digest on Islamic Law and Jurisprudence in Nigeria: Essay in Honour of Hon Justice Umar Faruk Abdullah (JCA), ed. Zakariyau I.O. (Auchi: Daru-Nur, 2003); M.A.B. Gaiya, 'Commentary on Professor Durham's Article: Nigeria State Religion Question in Comparative Perspective,' in Comparative Perspective on Shariah in Nigeria, ed. P. Ostien et al. (Ibadan: Spectrum Book Limited, 2005); P. Ostien, 'Four Articles on Shariah in Nigeria,' in Religion in the United States, ed. S.O.O. Amali et al. (Ibadan: American Studies Association of Nigeria, 2002); A.A. Nasiru, 'The Constitutionality of the Islamic Criminal Justice in Nigeria,' (A Paper presented at the $2^{\text {nd }}$ Combined Convocation of Justice Fati Abubakar Collect of Arts and Islamic Legal Studies Minna, 2005); Justice M.A. Oredola, 'The 1999 Constitution and the New Initiative on the Shariah between the Ideal and the Possible,' (National Conference on Application of Shariah, Bayero University, Kano, 1999). 
Based on all the aforementioned, this paper argues that those against the Shariah $^{76}$ utilise section 10 of the 1999 Constitution (as amended), which guarantees the principle of secularity of Nigeria as a country, is not based on sound legal reasoning. The reason for this that, the proposed tax reform will in no way prohibit or inhibit the performance of any act and or practice(s) of other religions in Nigeria.

Practically, in Nigeria today, it is very difficult to separate religion from the state. Nigeria is conceived of and ruled by people whose religion and philosophical beliefs are reflected in practice as well as in the running of state affairs. Not surprisingly the oath of office of the President, Governors, Deputy Governors, Ministers, Commissioners, Members of the National and State House Assembly, and judicial officers end with the phrase "So help me God".

Based on the above premise, this paper argues further that even though section 10 of the 1999 Constitution abhors the adoption of a state religion in Nigeria, it does not in any way prohibit a reform that will facilitate benefits to Muslims and the entire Nigerian population. In fact, up till now, the issue of categorising Nigeria as a "secular" state, based on section 10 is merely an assumption, because there is no clear provision in the now 2011 Constitution where the word "secular" is mentioned or specifies that Nigeria is a secular state..$^{77}$

In addition to the above, the Halliday's case is very instructive to law makers seeking legal reforms to facilitate Islamic finance in Nigeria. In that case, it was held that once such imposition (or reform) is for broad public

76 In 1999, when 19 Northern stage governors in Nigeria reverted to the use of Shariah Legal System in the criminal adjudications in their states, people like J. Odion, J. A. Yakubu, A. Adegbite, V.O Nmehiele, B.O. Nwabuze came out strongly to oppose the Islamic legal system. For details of some of their arguments, see A. Adegbite 'Shariah in the Context of Nigeria in Shariah Issue,' in The Shariah Working Paper for A Dialogue, DCC (Lagos: Committee of Concerned Citizen, 2000); V.O. Nmehielle, 'Shariah Law in Nigeria: To Implement or Not to Implement: Constitutionality is the Question,' Human Right Quarterly (2004); B.O. Nwabueze, 'Constitutional Problems of Shariah,' in The Shariah Working Paper for A Dialogue, DCC (Lagos: Committee of Concerned Citizen, 2000); J.A. Yakubu, The Dialectics of the Shariah Imbroglio in Nigeria (Ibadan: Demyax Law Books, 2003); J. Odion, 'The Advent of Shariah Law in the Nigerian Legal System: Constitutional Issues Arising,' Nigerian Law and Practice Journal, 4/2 (2000).

77 A.A. Nasiru, 'The Constitutionality of the Islamic Criminal Justice in Nigeria,' 10. 
interest, the religious belief in conflict with the payment of taxes affords no basis for resisting the tax.

Furthermore, a holistic reading of section 10 alongside other sections of the Constitution ${ }^{78}$ clearly allows for freedom of religion and by extension implementation of Shariah law and Islamic culture, among others. ${ }^{79}$ Thus, apart from the fact that section 38 implicitly recognises and sanctions the teaching of religion in public schools, section 247, 275-279, and 288 explicitly recognise and sanction the enforcement of at least a larger part of the religious law of Islam in the public courts. As such, embarking on a tax reform to facilitate or promote Shariah compliant financial transactions is therefore constitutional. The only place where this cannot be done is in a 'secular' state, which Nigeria is clearly not. Consequently, from all the aforementioned, it thus appears that while the power to reform taxes to facilitate a faith-based financial system would not be subject to an overriding prohibition of establishing a state religion, provided that the tax law is of general application enacted by the federal law makers and which will also result to general benefit of the citizenry.

\section{CONCLUSION AND RECOMMENDATIONS}

This paper has explored the relationship between religion and tax law. The constitutional provisions dealing with religion were analysed regarding whether or not they amounted to the secular nature of Nigeria. The federal legislature's powers to tax as well as its interaction with the religious guarantees in Nigeria were then appraised. Consequently, it has been argued that even though section 4(2) is subject to section 10, this does not prevent the federal legislature from introducing tax reforms to provide for faith-based finance since it would provide benefit to all Nigerians. Therefore, the position of this paper is that even though a tax reform to facilitate Islamic Finance in Nigeria is contending it is not contentious. This argument is premised on the fact that a

78 For example, sections 38 (This section is on the "Right to freedom of thought, conscience and religion" in Nigeria), 247 (This section is on the constitution of the court of Appeal in Nigeria wherein sub section (a) provides that a Shariah Court of Appeal is constituted if it consists of not less than three judges of the Court of Appeal learned in Islamic Personal Law), 275-279 (Which prohibit state religion in Nigeria) and 288 (Section 288 is on the appointment of persons learned in Islamic Personal and Customary Law).

79 P. Ostien and Gamaliel argued in a similar direction during the 1999 controversy on the introduction of Shariah Penal System in Nigeria and there was no any counter argument to negate the fact that sections 8, 247, 275-279 allows for and permitted the enforcement of religious law in public courts. 
careful and complete reading of section 10, alongside other sections that have to do with religion, allow for freedom of religion and the implementation of other aspects of Shariah law and Islamic culture. However, in order to make this reform viable, the paper recommends that:

1) The tax reform should be carried out following the formal procedures for constitutional reforms and amendment in Nigeria;

2) To guard against permitting what the Shariah prohibits or prohibit what the Shariah permits, it is important that opinion be sought from Islamic scholars as well as conventional tax law experts while embarking on the reform;

3) As an immediate solution, Nigeria can adapt the Islamic finance tax rules already in use in countries like Malaysia that have experienced what Nigeria is currently experiencing on how to tax Islamic financial products;

4) While adapting and applying Islamic law rules on commercial transactions, items by item analyses of each product should be used in bringing out the peculiarities that dichotomise Islamic financial products from conventional products;

5) Lastly, the proposed tax reform should not be preferential in nature, but responsive, enabling, and all encompassing. ${ }^{80}$

\section{REFERENCES}

A.A. Nasiru, 'The Constitutionality of the Islamic Criminal Justice in Nigeria,' (A Paper presented at the $2^{\text {nd }}$ Combined Convocation of Justice Fati Abubakar Collect of Arts and Islamic Legal Studies Minna, 2005).

A. Adegbite, 'Shariah in the Context of Nigeria in Shariah Issue' in The Shariah Working Paper for a Dialogue, DCC (Lagos: Committee of Concerned Citizen, 2000).

A.B. Dogarawa \& M.S. Bello, 'Achieving Financial Inclusion in Nigeria: What Role for Non-Interest Banking?' Bayero International Journal of Islamic Finance (2014): 92-93.

A.S. Hornby, Oxford Advanced Learners' Dictionary of Current English (London: Oxford University Press, 2004).

80 Just as suggested in the case of Australia by Brett F. \& Mahmood N., 'The Constitution and Islam: Are Tax Reforms Possible to Facilitate Islamic Finance?', 35 . 
A. Zubair, Sunnah: Its Adherents and Adversaries (Lagos: al-Madinah Heritage Publishers, 1995).

A. Zubair, The Major Sources on Islamic Law (Lagos: al-Madinah Heritage Publishers, 2005).

Abdulrazaq M.T. \& S.M. Olokooba, 'Tax Issues in Non-Interest Finance Transaction', (A Paper Presented at a 3 Day Workshop on Taxability of Non-Interest Finance in Nigeria, organized by the Federal Inland Revenue Services, Abuja, 9-10 October, 2013).

Abdulrazaq M.T., 'Are Islamic Financial Products Taxable in Nigeria?' (Unpublished paper, Author's private collection).

Abdulrazaq M.T., 'Banking and Taxation in the Name of God,'Business Day (Nigeria), 7 July 2011.

Abikan I.A., 'Islamic Banking as Non-Interest Banking: Fact or Fiction?' The Jurist (2011): 17.

Abikan I.A., 'Constitutional Impediments to the Total Enthronement of Shariah in Nigeria,' in A Digest on Islamic Law and Jurisprudence in Nigeria: Essay in Honour of Hon Justice Umar Faruk Abdullah (JCA), ed. Zakariyyah I.O. (Auchi: Daru-Nur, 2003).

Abū 'Ubayd, Kitāb al-Amwāl (Bayrūt: Dār al-Kutub, 1986).

A.D. Muhammed, N. Oladokun \& M.D.F. Amin 'Zakah Distribution among Asnaf in Wilayah and Selangor: An Analytical Hierarchy Process,' Bayero International Journal of Islamic Finance (2014): 39.

al-Ṭābarī, Tarīkh, vol. 2 (Cairo: Dār al-Ma'rifah, 1961).

B.D. Ahmad, 'Principles of Islamic Banking,' in Readings in Islamic Banking and Finance, ed. U.R. Shehu Aliyu et al. (Kano: International Institute of Islamic Banking and Finance, Bayero University, 2013), 60-75.

B.O. Nwabueze, 'Constitutional Problems of Shariah,' in The Shariah Working Paper for a Dialogue, DCC (Lagos: Committee of Concerned Citizen, 2000).

Bashir, 'Regulatory and Legal Framework for Non-Interest Finance in Nigeria', (A Paper presented at a 3 day workshop on Taxability of Non-Interest Finance in Nigeria, organized by the Federal Inland Revenue Services, Abuja, 9-10 October, 2013).

Brett F. \& Mahmood N., 'The Constitution and Islam: Are Tax Reforms Possible to Facilitate Islamic Finance?', Revenue Law Journal, 20/1 (2010): 1-36.

D.C. Dennett, Conversion and the Poll Tax in Early Islam (UK: Cambridge University Press, 1950). 
The Imbroglio On Tax Reforms to Facilitate Islamic Finance in Nigeria: A Contending But Not Contentious Constitutional Issue

El-Gamal, Islamic Finance: Law, Economics and Practice (UK: Cambridge University Press, 2009).

H.A. Yadudu, 'The Shariah Debate in Nigeria: Time for Reflections,' (A Paper delivered at the National Seminar on the Place of Women under the Shariah, Organised by Constitutional Rights Project, 2000).

I.A. Abikan, 'Constitutional Impediments to the Total Enthronement of Shariah in Nigeria,' in A Digest on Islamic Law and Jurisprudence in Nigeria: Essay in Honour of Hon Justice Umar Faruk Abdullah (JCA), ed. Zakariyau I.O. (Auchi: Daru-Nur, 2003).

J.A. Yakubu, The Dialectics of the Shariah Imbroglio in Nigeria (Ibadan: Demyax Law Books, 2003).

J. Odion, 'The Advent of Shariah Law in the Nigerian Legal System: Constitutional Issues Arising,' Nigerian Law and Practice Journal, 4/2 (2000): 2 .

John Onaiyekan, 'The Shariah in Nigeria: Issues and Perspectives,' (A Paper delivered at the National Seminar on Shariah Organised by Jamaatu Nasril Islam, 2000).

Joseph Edgar, 'Pastors Private Jets and their Taxes,' Daily Post $18^{\text {th }}$ September, 2015.

Justice M.A. Oredola 'The 1999 Constitution and the New Initiative on the Shariah between the Ideal and the Possible,' (National Conference on Application of Shariah, Bayero University, Kano, 1999).

Kemi Lawal \& Allwell Okpi, 'Okotie buys N120M Rolls Royce to Mark Pastoral Anniversary,' Sunday Punch, 22 ${ }^{\text {nd }}$ December 2013.

M.A.B. Gaiya, 'Commentary on Professor Durham's Article: Nigeria State Religion Question in Comparative Perspective,' in Comparative Perspective on Shariah in Nigeria, ed. P. Ostien et al. (Ibadan: Spectrum Book Limited, 2005).

M.A. Ishaq, S.U.R. Aliyu \& B.T. Jibril, 'Principle of Islamic Taxation' in Readings in Islamic Economy, ed. URA. Shehu et al. (Kano: International Institute of Islamic Banking and Finance, BUK, 2013), 94-106.

M.K. Adebayo \& S.M. Olokooba, 'The Memorandum of Understanding on Double Taxation between Nigeria and Kenya: An Appraisal', Africa Nazarene University Law Journal, $3 / 1$ (2015): 102-117.

M.N. Siddiqi, 'Muslim Economic Thinking: A Survey of Contemporary Literature,' in Studies in Islamic Economics, ed. Ahmed (Leicester UK: The Islamic Foundation, 1980). 
M. Obaidullah, Islamic Finance Services (Jeddah: King Abdul-Aziz University, 2006).

M.U. Chapra, Towards a Just Monetary System (Leicester UK: The Islamic Foundation, 1985).

N.A., 'The Private Jet, the Church and Nigerians,' Vanguard, 03 October 2013.

N. Yaqubu, 'Shariah Requirements for Conventional Banks,' Journal of Islamic Banking and Finance, 22 (2005): 1.

Niki Tobi (JCA), 'Law, Religion and Justice,' in Fundamental Legal Issues in Nigeria: Essays in Honour of Andrew Obaseki JSC, ed. O. Wole (Rtd) (Lagos: Patlink Publishers, 1995).

Oladoyin \& Olufemi, 'Taxation of Religious Bodies in Nigeria,' Modern Trend in Tax Law, Administration and Practice in Nigeria: Essay in Honour of Chief Olusola Adekanola, ed. O. Abifarin (Makurdi: Juniper Publications, 2013).

P. Ostien, 'Four Articles on Shariah in Nigeria,' in Religion in the United States, ed. S.O.O. Amali et al. (Ibadan: American Studies Association of Nigeria, 2002).

R.E. Krever \& G. Kewley, Australian Taxation: Principles and Practice (Cheshire : Longman Cheshire, 1987).

S.M. Olokooba, A.A. Kareem \& L.K Zakarriyah, 'Ambiguities in the Nigerian Tax Laws', Ife Juris Review, 3 (2014): 717-732.

S.M. Olokooba, 'Taxation of Islamic Banking Products under the Nigerian Laws: Issues, Problems and Prospects,' Bayero Journal of Islamic Law, 1/1 (2014): 5.

Sabahuddin Azmi, Islamic Economics (New Delhi, India: Goodword Books, 2004).

U. Hassan, 'An Overview of Non-Interest Finance,' (A Paper presented at A 3 Days Workshop on Taxability of Non-Interest Finance in Nigeria, organized by the Federal Inland Revenue Services, Abuja, 9-10 October, 2013).

V.C. Oba, 'Islamic Banking in Nigeria,' available at http://ssrn.com/ abstract $=2166538$, accessed on 12 July 2016 .

V.O. Nmehielle, 'Shariah Law in Nigeria: To Implement or Not to Implement: Constitutionality is the Question,' Human Right Quarterly (2004): 742.

Z. Iqbal, 'Islamic Financial Systems', Journal of Finance and Development, 34/2 (1997): 2. 


\section{Statutes}

Bank and Other Financial Institutions Act.

Central Bank of Nigeria Act.

Companies and Allied Matters Act.

Companies Income Tax Act.

Federal Inland Revenue Services Act (2007).

Goods and Services Tax Act (1999).

Laws of the Federation of Nigeria (2004).

Personal Income Tax Act (2004).

\section{Cases}

Akinosho v. Enigbokan (1955) 2 N.L.R 88.

Beck v. Smith (1836) 2 M\&W 191, 195.

Church of the New Faith v. Commissioner of Payroll TR 794.

Halliday v. The Commonwealth of Australia (2000) FCA 950.

Heydon's case (1584) 3 Co: Rep 7.

Michigan Employment Sec Commission v. patt 4 Mich-App 24414 N.W 2nd 663.

Osborne v. Commonwealth (1911) 12 CLR 321.

$R$ v. Bangaza (1960) 5 F.S.C. 1.

$R$ v. Barger (1908) 6 CLR 41.

Shell v. FBIR (2004) FNLR 859 at 46. 
Jurnal Syariah, Jil. 25, Bil. 3 (2017) 505-530 